\title{
SAVANNAH RIVER SITE RADIONIODINE ATMOSPHERIC RELEASES AND OFFSITE MAXIMUM DOSES (U)
}

by WSRC Contact - W. H. Carton

Westinghouse Savannah River Company

SRL-ETS- $-90-317$

Savannah River Site

Aiken, South Carolina 29808

Other Authors:

W. L. Marter

This paper was prepared in connection with work done under Contract No. DE-AC09-89SR18035 with the U. S. Department of Energy. By acceptance of this paper, the publisher and/or recipient acknowledges the U. S. Government's right to retain a nonexclusive, royalty-free license in and to any copyright covering this paper, along with the right to reproduce and to authorize others to reproduce all or part of the copyrighted paper.

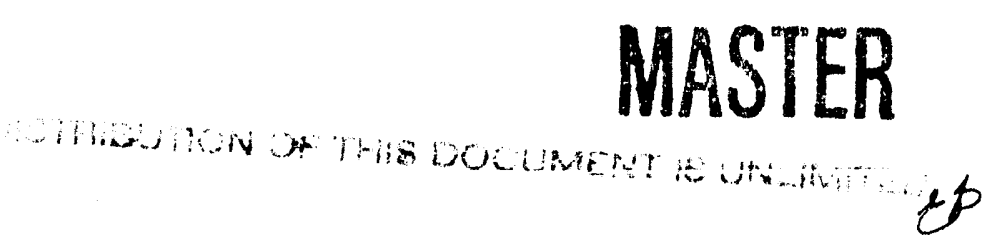


WESTINGHOUSE SAVANNAH RIVER COMPANY

SRL-ETS-900317

SAVANNAH RIVER LABORATORY

November 1, 1990

To: $\quad$ A.L. Boni, 773A

From: W.L. Marter, 773-42A wo Whate

SAVANNAH RIVER SITE RADIOIODINEATMOSPHIERIC RELEASFS AND OFFSITE MAXIMUM DOSES (U)

Ref: Marter, W.L., Summary of Savannah River Site Radioiodine Releases and Offsite Maximum Doses (U), SRL-ETS-900315, July 26, 1990.

\section{INTRODUCTION}

The reference memorandum was issued to summarize our current knowledge of releases of radioiodines and resultant maximum offsite doses. This memorandum supplements the reference memorandum by providing more detailed supporting technical information.

Doses reported in this memorandum from consumption of the milk containing the highest I-131 concentration following the 1961 I-131 release incident are about 1\% higher than reported in the reference memorandum. This is the result of using unrounded I-131 concentrations of I-131 in milk in this memo.

It is emphasized here that this technical report does not constitute a dose reconstruction in the same sense as the dose reconstruction effort currently underway at Hanford. This report uses existing published data for radioiodine releases and existing transport and dosimetry models.

\section{SUMMARY}

Radioisotopes of iodine have been released to the atmosphere from the Savannah River Site since 1955. The releases, mostly from the 200-F and 200-H Chemical Separations areas, consist of the isotopes, I-129 and I-131. Small amounts of I-131 and I-133 have also been released from reactor facilities and the Savannah River Laboratory. These isotopes, and many other short-lived fission product and activation product iodine isotopes (including stable 1-127), are produced by reactor irradiation of fuel and target elements.

Over the 1954-1989 operating history of the site, it is estimated that 5.7 curies of I-129 and 2520 curies of I-13I (see Figure 1 for I-131 releases) have been released to the atmosphere. All of the I-129 and I-131, with the exception of about 153 curies of I-131 discharged from F-Area during May 29 - June 23, 1961, was released as the result of routine operations.

About 84 percent of the I-131 (2123 curies) was released during the 1955-1959 time period. The year of maximum release was 1956, with a release of 1580 curies of I-131. The I-131 (half-life $=8.04$ days) releases during this time period were the result of shorter "cooling" time (i.e., storage time to allow decay of I-131 and other 
short-lived radionuclides) in the 1950 's for reactor products before chemical processing, with a resulting higher inventory of I-131 in the processed material. lodine-129, with a half-life of 16 million years, was little affeited by the cooling times at any time of plant operation. As a consequence, I-129 has been released more or less uniformly over the 35-year operating history, never exceeding a curie per year (5.7 curies since startup).

Maximum offsite doses from routine radioiodine releases were recalculated for all major pathways of exposure with environmental dosimctry models currently in use for environmental assessments at SRS, employing a 1982-86 metecrological data base. The most recent ICRP 56 model for internal dosimetry (ICRP 1989) was used and compared with older ICRP 30 model (DOE 1988). A summary of the calculated doses appears in the Table 1. An adult, living on the site perimeter from 1954 through 1989 at the location of maximum exposure and producing all of his food at that location could have received a total I-131 thyroid dose (ICRP 56) of $781 \mathrm{mrem}$ with 489 mrem of this occurring in 1956. A child living at the same location on the site perimeter in 1956 could have received an I-131 thyroid dose of 1540 mrem, about 3 times higher than an adult. Greater than 90 percent of these doses would have resulted from consumption of milk and vegetables produced at the place of residence at the site perimeter (Table 1). These maximum doses are considered conservative because maximum intakes of food (meat, milk, and vegetables) and inhaled air were used in the calculations. In addition, these hypothetical individuals were assumed to remain constantly at the point of maximum exposure at the site perimeter.

Following the 1961 I-131 release incident due to "short-cooled" fuel, I-131 was detected in milk produced around the site, with a maximum concentration of 5400 pCi per liter found in milk from a farm cow on pasture about two miles from the northeast site perimeter. At that time, it was calculated that a dose of $1200 \mathrm{mrem}$ to a child thyroid and 140 mrem to an adult thyroid (Marter 1963) could have resulted from milk consumption based on a conservative 8 day half-time of I-131 in milk. Thyroid doses recalculated with a more recent internal ICRP 56 dosimetry method and the observed half-time of I-131 in milk of 5 days (Marter 1963) are reduced by a factor of 3 from the 1961 results. The recalculated doses are $277 \mathrm{mrem}$ to a child thyroid and $53 \mathrm{mrem}$ to an adult thyroid. In addition, the current technology allows calculation of $497 \mathrm{mrem}$ to an infant thyroid and 112 mrem to a teen thyroid. Doses calculated for this release incident with ICRP 56 dose factors are shown in Table 1. Doses calculated with older ICRP 2 (Hoenes 1977) and ICRP 30 internal dosimetry models are shown for comparison.

Current recommended dose limits for members of the public (ICRP 1977, NCRP 1987 , and DOE 1990) are 100 mrem per year effective dose equivalent (EDE)* for frequent or continuous exposure and $500 \mathrm{mrem}$ per year EDE for infrequent exposures. These limits apply to all age groups.

* Efrective Dose Equivalent is the sum of the products of organ dose equivalents and weighting factors. The weighting factors, as developed in ICRP 1977, are based on the risk of a serious genetic or somatic (cancer) effect from radiation doses to individual organs relative to the risk from an equal dose to the total body. In this scheme, the weighting factor for the thyroid is 0.03 . In other words, a radiation dose to the thyroid is about $1 / 30$ th as effective in causing a serious effect as the same dose to the total body. 
In the case of I-129, I-131, and I-133, for which the only significantly exposed organ is the thyroid, the EDE limits can be converted to thyroid dose limits by multiplying by 30 . On this basis, the current derived thyroid dose limit for members of the public would be about 3,000 mrem per year for frequent or continuous exposures and $15,000 \mathrm{mrem}$ per year for infrequent exposures. The maximum thyroid dose per year of $1,550 \mathrm{mrem}$ (child) in 1956 from all pathways from routine operations and 497 mrem (infant) in 1961 from milk consumption following the I-131 release incident, are all well below the derived thyroid dose limits.

\begin{tabular}{lll} 
& Doses, mrem & \\
\cline { 2 - 3 } & Thyroid & EDE \\
1956 - child (all pathways) & 1,550 & 46 \\
1961 - infant (milk only) & 497 & 15 \\
ICRP recommended limit & - & 100
\end{tabular}

\section{RADIOIODINE RELEASES}

Fission product and activation product isotopes of iodine are produced by neutron irradiation of fuel and target materials in Savannah River Site reactors. Many of these isotopes have short half-lives and decay rapidly after protuction. Typically, at the end of irradiation, only $20 \%$ of the radioiodines remains in the fuel and targets after 24 hours, $0.04 \%$ at 60 days, and $0.0000002 \%$ at 200 days. Under ideal conditions, all of the radioiodines would be retained in the fuel and target elements during the 200-day "cooling period" (storage for decay of I-131 and other short-lived radionuclides) before the materials are chemically processed. However, small amounts of I-131 have been released from reactor buildings because of minor cladding defects in some fuel and target elements. Small amounts of I-131 and I-133 have also been released from Savannah River Laboratory facilities.

Most of the radioiodines have been released from the 200-F and 200-H chemical separation facilities. By the time of chemical processing, usually at least 200 days after the end of irradiation, only I-129 (half-life $16,000,000$ years) and I-13I (half-life 8.04 days) remain in any measurable quantities. During fuel and target dissolution, a large fraction of the radioiodines are evolved but are removed from the dissolver offgas by emission controls. Radioiodine which is not evolved as a vapor during dissolution remains in the liquids. During subsequent processing of these liquids, some radioiodine is released as a vapor to the atmosphere via the vessel vent offgas system to the sandfiltsi-exhaust stack. This has been the major source of radioiodine releases at the Savannah River Site.

The total releases of radioiodines at the Savannah River Site for the entire period of operation (1954-1989) were 5.7 curies I-129, 2520 curies I-131, and 0.01 curie I-133 (Table 2 and Figure 1) (Hetrick 1990, Zeigler 1988, Zeigler 1987, Mikol 1988

). The half-life of I-133 (20.8 hours), which was released from the Savannah River Laboratory in 1973, is so short that it does not have a significant impact on the major pathways of exposure (milk and vegetables).

I-129, with a half-life of $16,000,000$ years, undergoes little decay during the normal cooling time between end of reactor irradiation and chemical processing. Because of this, I-129 has been released more or less uniformly over the 35-year operating period with releases being less than a curie per year (5.7 curies in 35 years). In contrast, shorter cooling times in the early years of plant operation resulted in 
higher routine releases of I-131 (half-life 8.04 days). Of the 2520 curies of I-131 released at SRS, 2123 curies $(84 \%)$ were released in the 1955-1959 time period. The year of maximum release was 1956, when 1580 curies were released.

\section{DOSES - ROUTINE RELEASES}

Maximum offsite doses from routine radioiodine releases were calculated with the current dosimetry model described in Appendix A of this report. Doses were calculated for all significant pathways of exposure, i.e., external dose from plume and ground and internal dose from inhalation and consumption of milk, meat, and vegetative foods. This model employed an SRS data base for meteorology (1982-86) and an ICRP 56 data base for internal dose factors (ICRP 1989). Calculations were also made employing an ICRP 30 data base for internal dose factors (DOE 1988) for comparison. Calculated doses are shown by year in Tables 2 and 3 and Figures 3 and 4.

A summary of doses from routine releases of I-129 and I-131 is shown in Table 1. An adult, living on the site perimeter during the entire $1954-89$ period at the location of maximum exposure and producing all of his food at the same location could have received an I-131 thyroid dose of $781 \mathrm{mrem}$ and an I-129 thyroid dose of $162 \mathrm{mrem}$, a total of $943 \mathrm{mrem}$. The maximum annual thyroid dose would have occurred in 1956 and would have been $489 \mathrm{mrem}$ from I-131 and 6 mrem from I-129, a total of $496 \mathrm{mrem}$. A child at the same location on the site perimeter in 1956 could have received an I-131 thyroid dose of $1540 \mathrm{mrem}$ and an 1-129 thyroid dose of $9 \mathrm{mrem}$, a total dose of $1550 \mathrm{mrem}$. These maximum doses are considered conservative because maximum intakes of food (meat, milk, and vegetables) and inhaled air were used in the calculations. Greater than $90 \%$ of the thyroid doses were calculated to be from the milk and vegetable pathways (Table 1). The milk pathway accounts for $99 \%$ of the dose to an infant.

\section{RADIOIODINE RELEASE INCIDENT - 1961}

About 153 curies of I-131 were released from an SRS chemical processing plant during May 29 - June 23, 1961 as the result of unintentionally processing some very short-cooled fuel (Marter 1963). This was confirmed by the detection of short halflife U-237 in a process stream. About 67\% (103 curies) of the I-131 was released during the first eight days. Prevailing southwest winds and atmospheric inversions dispersed the radioiodine mainly to the northeast of the plant where it was detectable in air, vegetation, and milk.

Serial sampling showed that the effective half-time of I-131 in vegetation and milk was 4 to 5 days. The maximum concentration of I-131 in milk from sampling 48 farms and dairies during the peak period of June 5 and 6 was 5400 pCi per liter*. The maximum

- The maximum concentration of I-131 measured in an individual milk sample was $5451 \mathrm{pCi} /$ liter. Various reports have rounded this value to 5400 and 5500 $\mathrm{pCi} /$ liter. Calculations in this report are based on a concentration of 5451 $\mathrm{pCi} /$ liter, resulting in thyroid doses about $1 \%$ higher than given in the reference memorandum.

sample was obtained from a farm about 2 miles northeast of the site perimeter. The only other fresh, locally produced foods available during this period in early June 
were eggs and peaches. Fresh eggs from the farm where the maximum milk concentration was found contained an average of $33 \mathrm{pCi}$ per egg. Peaches from an area of high deposition showed no evidence of radiolodine. lodine-131 concentrations in air in the area of highest offsite concentration for the wesk ending June 7 ranged from 1 to 5 pCi per cubic meter.

\section{DOSE - 1961 I-131 RELEASE INCIDENT}

From the monitoring data presented above, it was obvious that the milk pathway would be the major source of offsite exposure. To avoid underestimating the dose from ingestion of milk, original dose calculations were made with an assumed 8-day half-time of I-131 in milk instead of the 5-day half-time actually observed (Marter 1963). The original dose calculations indicated the maximum probable dose to a child's thyroid of 1200 mrem and 140 mrem to an adult's thyroid. A recalculation of the thyroid doses using the same assumptions as used at the time of the release incident but using a 5-day half-time of I-131 in milk gave maximum thyroid doses of 761 mrem to a child and 76 mrem to an adult.

During the week ending June 7, 1961, the average concentration in air in the area of maximum offsite $\mathrm{I}-131$ air concentration ranged from 1 to $5 \mathrm{pCi} / \mathrm{m}^{3}$ (Marter 1963). Immersion (plume) thyroid dose from one week of exposure to this contaminated air would range from $4 \times 10^{-5}$ to $2 \times 10^{-4}$ mrem. Thyroid dose from inhalation of this air would range from 1.4 to 6.9 mrem for a child and 0.3 to 1.5 mrem for an adult.

The average concentration of $\mathrm{I}-131$ in eggs (the only available food in early June which contained measurable I-131) was $33 \mathrm{pCi} / \mathrm{egg}$ at the farm exhibiting the highest milk concentration. At the consumption rate of 2 eggs per day and an assumed 5-day half-time in eggs, the dose to a child and adult thyroid would be 7.1 and 0.7 mrem, respectively.

Based on the foregoing discussion of I-131 doses from other pathways, greater than $95 \%$ of the thyroid dose for a child would have resulted from the milk pathway.

The U.S. Nuclear Regulatory Commission published in 1977 standardized agespecific intake parameters for meat, milk, vegetables, and inhaled air for maximum individuals to be used in environmental dose assessments (NRC 1977). These parameters are used in the current environmental dosimetry models employed for environmental assessments at SRS. These were used to recalculate thyroid doses from consumption of the milk containing the maximum concentration of I-131. The NRC milk intake parameters were used to calculate thyroid doses with internal dose factors published in ICRP Publications 2, 30, and 56. These publications, published over the 1960 - 1989 period, reflect increasing sophistication with time as more physiological and radiological data became available. ICRP Publication 56 reflects the most up to date and accurate internal dose methodology. Doses calculated with the three sets of internal dose factors are shown in Table 1. This table also shows doses calculated by all other methods described in this section. Adult thyroid doses ranged from 53 to $65 \mathrm{mrem}$ and younger maximum age groups ranged from 103 to 497 mrem. The values considered to be most accurate and reflect current technology are those listed for ICRP 56, i.e., 53 mrem for an adult thyroid and 497 mrem for an infant thyroid.

\section{PUTTING THYROID DOSES INTO PERSPECTIVE}

Organs of the human body vary widely in their sensitivity to radiation. Because of 
this, scientists have devised a unit of dose, effective dose equivalent (EDE), that can relate the dose to individual organs to an equivalent total body dose (ICRP 1977). For example, a dose of $1 \mathrm{rem}$ to the thyroid is equal in serious genetic or somatic risk to about $1 / 30$ rem EDE.

Current recommended dose limits for members of the pusblic (ICRP 1977, NCRP 1987, and DOE 1990) are 100 mrem per year EDE (summation of weighted organ dose equivalents) for frequent or continuous exposure and 500 mrem per year EDE for infrequent exposures. These limits apply to all age groups. These EDE limits can be converted to thyroid dose limits by multiplying by 30 . On this basis, the current thyroid dose limit for members of the public would be about 3,000 mrem per year for frequent or continuous exposures and $15,000 \mathrm{mrem}$ per year for intrequent exposures. The maximum thyrold dose per year of $1,550 \mathrm{mrem}$ (child) in 1956 from routine operations and $497 \mathrm{mrem}$ (infant) in 1961 from milk consumption following the I-131 release incident, are all well below the derived thyroid dose limits.

The year of maximum EDE from I-129 and I-131 releases was 1956 with maximum adult doses of $14.9 \mathrm{mrem}$ EDE and maximum child doses of $45.8 \mathrm{mrem}$ EDE. These doses can be compared with the annual dose of $295 \mathrm{mrem}$ EDE from natural sources of radiation in this area of the country and $65 \mathrm{mrem}$ EDE from medical radiation, consumer products, and other sources of manmade radiation.

Medical doctors used I-131 in the past in diagnostic procedures to determine if the thyroid was functioning properly. In two Swedish studies of 10,000 and 35,000 people who received diagnostic doses of I-131 averaging $50 \mathrm{rad}$, there was no evidence of a significantly increased risk of thyroid cancer (BEIR 1990). Doctors use larger amounts of I-131 to treat patients whose thyroids are not working properly. These therapeutic procedures, which are intended to make the thyroid stop functioning, typically result in a dose of 5,000 - 10,000 rad to the thyroid.

"Radiation doses are sometimes expressed in terms of rad (radiation absorbed dose). A dose of one rad means the absorption of 100 ergs of energy per gram of absorbing material. Since one rad of absorbed dose from different types of radiation can have different biological effects in man, the unit of rem (dose equivalent) was developed. Rem dose is obtained by multiplying rad dose by a quality factor to put doses on a common scale of biological effect (carcinogenesis) on humans for all types of ionizing radiation. The quality factor for $\mathrm{x}$-rays, gamma rays, and beta particles is one. Thus, in the case of internal doses from $x$-rays, gamma rays, and beta particles, one rad is equal to one rem.

The calculations in this report for thyroid dose from radioiodines follow the ICRP convention (ICRP 1977 and ICRP 1978) of calculating the rem dose equivalent by multiplying the rad absorbed dose by a quality factor of 1 . Thus, a rad of thyroid dose is equal to a rem of thyroid dose. Rem thyroid organ dose should not be confused with rem effective dose equivalent which is the summation of weighted organ dose equivalents and is discussed in the box on page 2. 
SRL-ETS-900317

\section{REFERENCES}

BEIR, 1990. Health Effects of Exposure to Low Levels of Ionizing Radiation - BEIR V. Committee on the Biological Effects of Ionizing Radiations, Board on Radiation Effects Research, Commission on Life Sciences, National Research Council, National Academy of Science.

DOE, 1988. Internal Dose Conversion Factors for Calculation of Dose to the Public. DOE/EH-0071, U.S. Department of Energy. (Based on: Limits for Intakes of Radionuclides by Workers. ICRP Publication 30, International Commission on Radiological Protection, 1978.)

DOE, 1990. Radiation Protection of the Public and Environment. DOE Order 5400.5, U.S. Department of Energy.

FDA, 1978. Accidental Radioactive Contamination of Human and Animal Feeds and Potassium Iodide as a Thyroid-Blocking Agent in a Radiation Emengency. Federal Register Vol.43, No.242, pp 58790 - 58800, U.S. Department of Health, Education, and Welfare (Food and Drug Administration).

Hetrick, C.S. and D.K. Martin, 1990. Radioactive Releases at the Savannah River Site 1954 - 1988 (U). WSRC-RP-89-737, Westinghouse Savannah River Company

Hoenes, G.R. and J.K. Soldat, 1977. Age-Specific Radiation Dose Commitment Factors for a Chronic One-Year Intake. NUREG-0172, Battelle Pacific Northwest Laboratories for U.S. Nuclear Regulatory Commission. (Based on: Report of ICRP Committee II on Permissible Dose for Internal Radiation (1959). ICRP Publication 2, International Commission on Radiological Protection, 1960.)

ICRP, 1977. Recommendations of the International Commission on Radiological Protection. ICRP Publication 26, International Commission on Radiological Protection.

ICRP, 1978. Limits for Intakes of Radionuclides by Workers, ICRP Publication 30, International Commission on Radiological Protection.

ICRP, 1989. Age-Dependent Doses to Members of the Public from Intake of Radionuclides: Part 1. ICRP Publication 56, Annals of the ICRP, International Commission on Radiological Protection.

Marter, W.L., 1990. Offsite Doses for 1989 Environmental Report. SRLETS-900151, Savannah River Laboratory, Aiken, SC.

Mikol, S.C., L.T. Burckhalter, J.L. Todd, and D.K. Martin, 1988. Savannah River Plant Environmental Report - Annual Report for 1987. DPSPU-88-30-1, Vol.1, Savannah River Plant, Aiken, SC.

NCRP, 1985. Induction of Thyroid Cancer by Ionizing Radiation. NCRP Report 80, National Council on Radiation Protection and Measurements.

NCRP, 1987. Recommendations on Limits for Exposure to Ionizing Radiation. NCRP 
Report 91, National Council on Radiation Protection and Measurements.

NRC, 1977. Calculation of Annual Doses to Man from Routine Releases of Reactor Effluents for the Purpose of Evaluating Compliance with 10 CFR Part 50, Appendix I. Regulatory Guide 1.109, U.S. Nuclear Regulatory Commission.

Zeigler, C.C. and I.B. Lawrimore, 1988. Releases of Radiouctivity at the Savannah River Plant. DPSPU-86-25-1, Savannah River Plant, Aiken, SC.

Zeigler, C.C., E.M. Heath, L.B. Taus, and J.L. Todd, 1987. Savannah River Plant Environmental Report - Annual Report for 1986. DPSPU-87-30-1, Vol.1, Savannah River Plant, Aiken, SC 


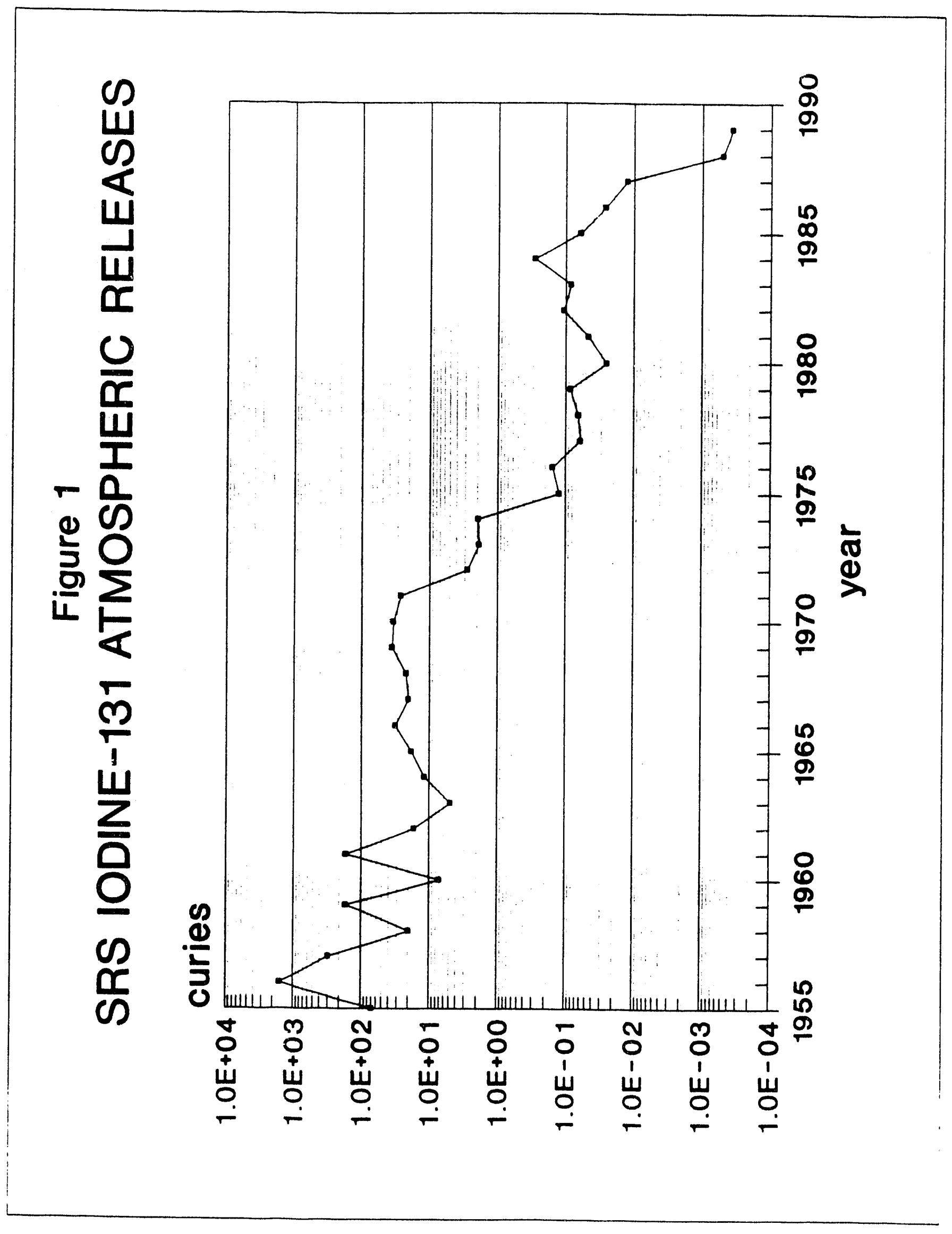




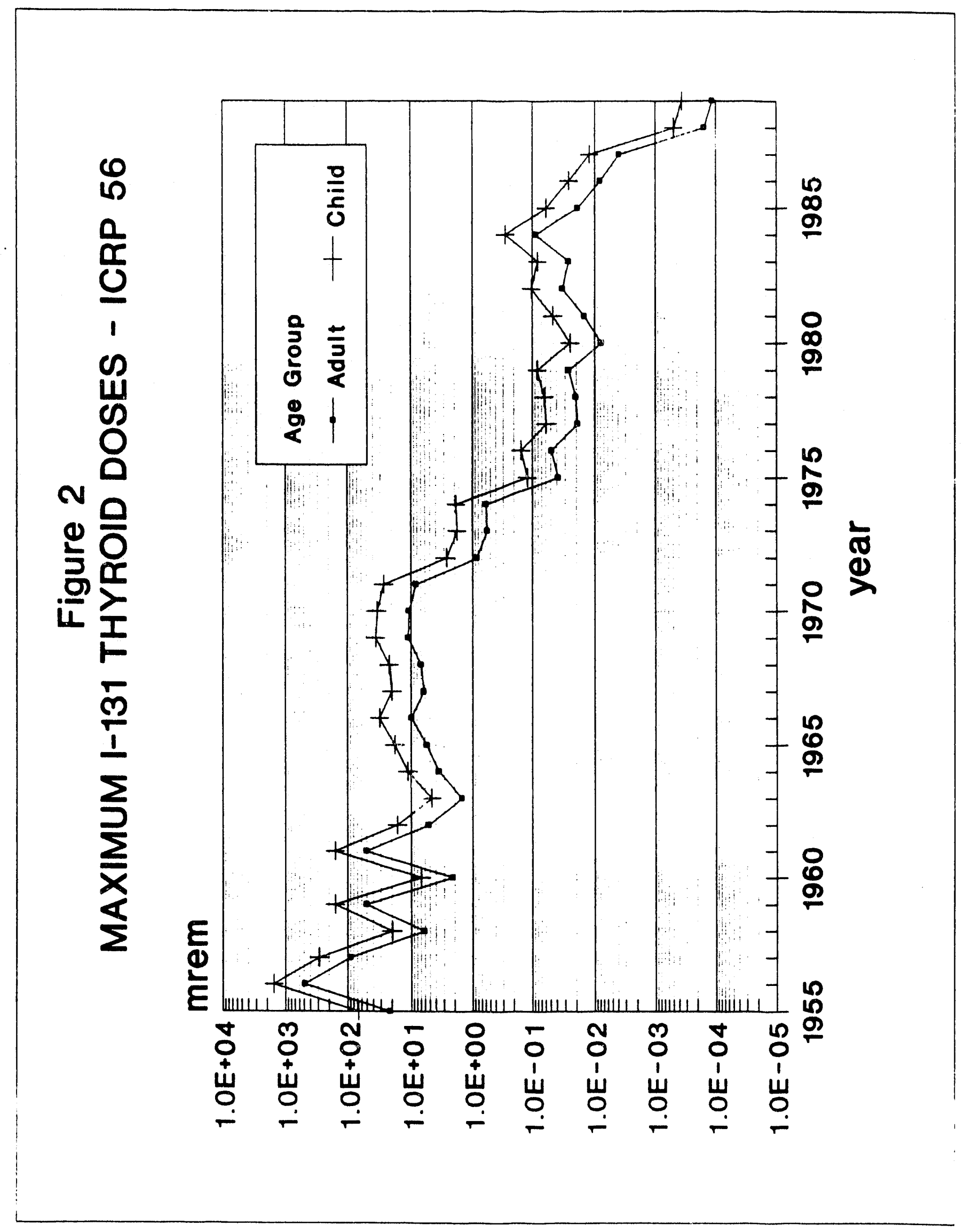




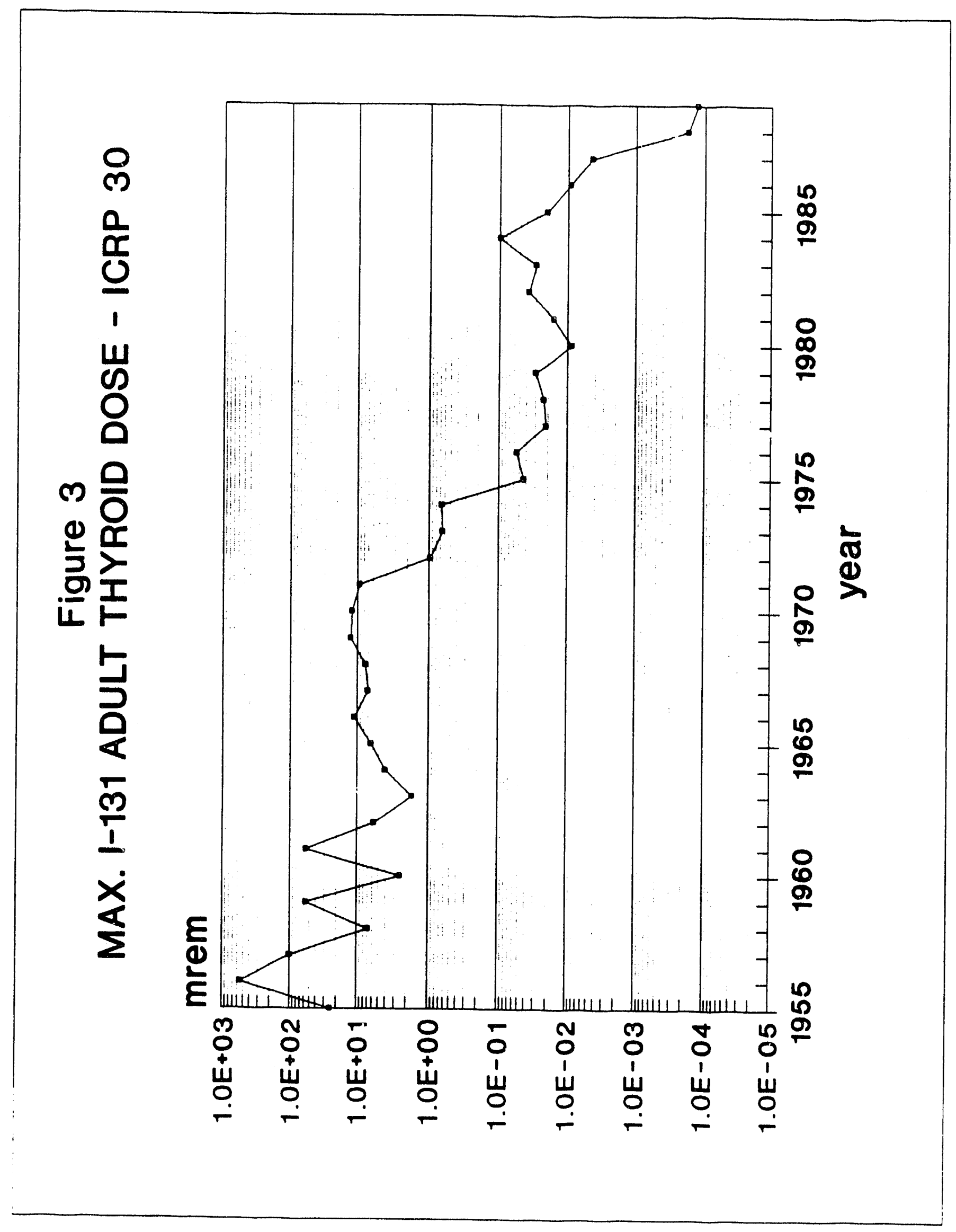


Table 1

SUMMARY OF ATMOSPHEAIC RMDIOIOOME REIEASES AND WWXIMITH OFFSITE DOSES FROM ALL PATHWAYS

\begin{tabular}{|c|ll|}
\hline \multirow{3}{*}{ Letope } & \multicolumn{3}{|l|}{ Releases, curles } \\
\cline { 2 - 3 } & $1954-1080$ & 1956 \\
\hline $1-129$ & $5.67 E+00$ & $2.12 E-01$ \\
I-131 & $2.52 E+03$ & $1.68 E+03$ \\
\hline
\end{tabular}

\begin{tabular}{|c|c|c|c|c|c|c|}
\hline \multirow[b]{3}{*}{ Year } & \multicolumn{4}{|c|}{ Adult Dose, mrem } & \multirow{2}{*}{\multicolumn{2}{|c|}{$\begin{array}{l}\text { Child Dose, mirem } \\
\text { ICAPSs }\end{array}$}} \\
\hline & \multicolumn{2}{|c|}{ ICAP30 } & \multicolumn{2}{|l|}{ ICRPSE } & & \\
\hline & EDE & Thyroid & EDE & Thyrold & EDE & Thyroid \\
\hline 105480 & & & & & & \\
\hline $\begin{array}{l}-120 \\
-131\end{array}$ & $\begin{array}{l}5.86 E+00 \\
2.00 E+01\end{array}$ & $\begin{array}{l}1.04 E+02 \\
8.00 E+02\end{array}$ & $\begin{array}{l}5.00 E+00 \\
2.35 E+01\end{array}$ & $\begin{array}{l}1.02 E+02 \\
7.81 E+02\end{array}$ & $\begin{array}{l}M \\
M\end{array}$ & MA \\
\hline Total & $2.18 E+01$ & $1.07 E+03$ & $2.05 E+01$ & $0.43 E+02$ & $\mathbf{M}$ & $\mathrm{MA}$ \\
\hline 1058 & & & & & & \\
\hline $\begin{array}{l}-120 \\
1-131\end{array}$ & $\begin{array}{l}2.18 E-01 \\
1.03 E+01\end{array}$ & $\begin{array}{l}7.21 E+\infty 0 \\
8.51 E+\infty 2\end{array}$ & $\begin{array}{l}1.07 E-01 \\
1.47 E+01\end{array}$ & $\begin{array}{l}\text { C.04E }+00 \\
4.80 E+02\end{array}$ & $\begin{array}{l}\text { 2.00E-01 } \\
\text { 4.6xE+01 }\end{array}$ & $\begin{array}{l}0.418 E+\infty 00 \\
1.915+03\end{array}$ \\
\hline Total & $1.355+01$ & $8.50 E+\infty 2$ & $1.40 E+01$ & $4.002+02$ & $4.60 E+01$ & $1.865+03$ \\
\hline
\end{tabular}

EDE - Efiectivo Dose Equhalent.

MA - Not applicabls since a parson would not remain a chlld during this entire period.

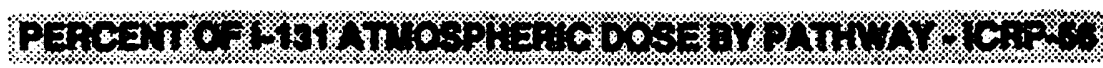

\begin{tabular}{|c|c|c|c|c|c|c|c|c|}
\hline \multirow[b]{2}{*}{ Pathway } & Intant & & Child & & \multicolumn{2}{|l|}{ Teen } & \multicolumn{2}{|l|}{ Aduln } \\
\hline & EDE & Thyrold & EDE & Thyroid & EDE & Throld & EDE & Throld \\
\hline Plume & 0.0 & 0.0 & 0.0 & 0.0 & 0.0 & 0.0 & 0.0 & 0.0 \\
\hline Ground & 0.2 & 0.0 & 0.2 & 0.0 & 0.3 & 0.0 & 0.5 & 0.0 \\
\hline Veget & 0.0 & 0.0 & 41.7 & 41.6 & 47.3 & 47.5 & 61.5 & 61.7 \\
\hline Meat & 0.0 & 0.0 & 1.8 & 1.8 & 2.1 & 21 & 3.1 & 3.2 \\
\hline Cow Mllk & 90.3 & 9.4 & 86.6 & 56.7 & 40.0 & 49.1 & 33.7 & 33.0 \\
\hline inhal & 0.8 & 0.8 & 0.8 & 0.8 & 1.3 & 1.3 & 12 & 1.9 \\
\hline
\end{tabular}

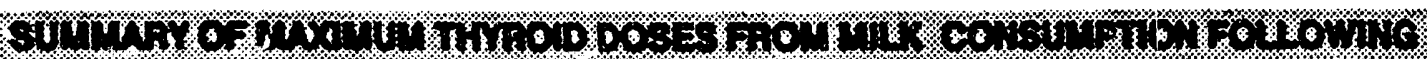
1061 H.13T RaZLSISE WCDENT

\begin{tabular}{|l|r|r|r|}
\hline \multirow{2}{*}{ Age Group } & \multicolumn{3}{|c|}{ Thyroid Doce, mrem } \\
\cline { 2 - 4 } & ICRP 2 & ICRP 30 & ICRP 56 \\
\hline & & & \\
Infant & 494 & NA & 497 \\
Child & 203 & NA & 277 \\
Teen & 103 & NA & 112 \\
Adult & 65 & 60 & 53 \\
\hline
\end{tabular}

NA - Not applicable. Age-specific dose factors not provided by ICRP 30. 
Table 2

RADIOIODINE ATMOSPHERIC RELEASES AT SRS

\begin{tabular}{|c|c|c|c|}
\hline \multirow{2}{*}{ YEAR } & \multicolumn{3}{|c|}{ Roleaces, curice } \\
\hline & $1-129$ & $\mid-131$ & $1-133$ \\
\hline 1054 & & & \\
\hline 1955 & 2.12E-01 & C.02E +01 & \\
\hline 1986 & $2.12=01$ & $1.60 E+03$ & \\
\hline 1957 & $2.12 E-01$ & $2.02 E+02$ & \\
\hline 1958 & $2.12 E-01$ & $1.00 E+01$ & \\
\hline 1050 & $2.125-01$ & $1.625+02$ & \\
\hline 1800 & $2.12=-01$ & $7.03 E+\infty 0$ & \\
\hline 1881 & $2.12 E-01$ & $1.62 E+02$ & \\
\hline 1902 & $2.125-01$ & $1.6 x \varepsilon+01$ & \\
\hline 1963 & $2.12 x-01$ & $4.825+\infty 0$ & \\
\hline $19 e 4$ & $2.12 E-01$ & $1.18 E+01$ & \\
\hline 1965 & $2.12 E-01$ & $1.81 E+01$ & \\
\hline 1968 & $2.12 E-01$ & $3.1 e E+01$ & \\
\hline 1967 & $2.12 E-01$ & $2.01 E+01$ & \\
\hline 1968 & $2.12=-01$ & $2.21 E+01$ & \\
\hline 1909 & $2.12 E-01$ & 3.60E+01 & \\
\hline 1970 & 2.12E-01 & 3.44E+01 & \\
\hline 1971 & $2.12 E-01$ & 2. $68 E+01$ & \\
\hline 1972 & 2.12E-01 & $2.74 E+\infty 0$ & \\
\hline 1973 & $2.12 E-01$ & $1.88 E+\infty 0$ & 1.00E-02 \\
\hline 1974 & $1.70 E-01$ & $1.01 E+\infty$ & \\
\hline 1975 & $1.40 E-01$ & $1.23 E-01$ & \\
\hline 1976 & $1.50 E-01$ & $1.555-01$ & \\
\hline 1077 & $1.40 E-01$ & C.00E-02 & \\
\hline 1978 & $1 .: X E-01$ & 6.5AE-02 & \\
\hline 1970 & $1.30 E-01$ & $8.435-02$ & \\
\hline 1880 & $1.00=-01$ & 2.51E-02 & \\
\hline 1881 & 1.e0E-01 & $4.70 E-02$ & \\
\hline 1902 & $5.005-02$ & $1.00: E-01$ & \\
\hline 1083 & $4.10 E-02$ & $8.41 E-02$ & \\
\hline 1024 & 3.5AE-02 & $2.82=01$ & \\
\hline 1985 & 6.50E-02 & $6.06 \varepsilon-02$ & \\
\hline 1986 & 8.70E-02 & $2.045-02$ & \\
\hline 1987 & $7.20 E-02$ & $1.26 E-02$ & \\
\hline 1988 & 6.30E-02 & $4.08 E-04$ & \\
\hline 1989 & $5.10 E-02$ & 3.64E-04 & \\
\hline Totals & $5.67 E+00$ & $2.52 E+03$ & \\
\hline
\end{tabular}

Atmospheric $\mathrm{l}-129$ releases from the separations areas were calculated for the 1955-1973 period and tabulated on a prorated annual basis. Releases for the 1974-1989 period were calculated annually. 


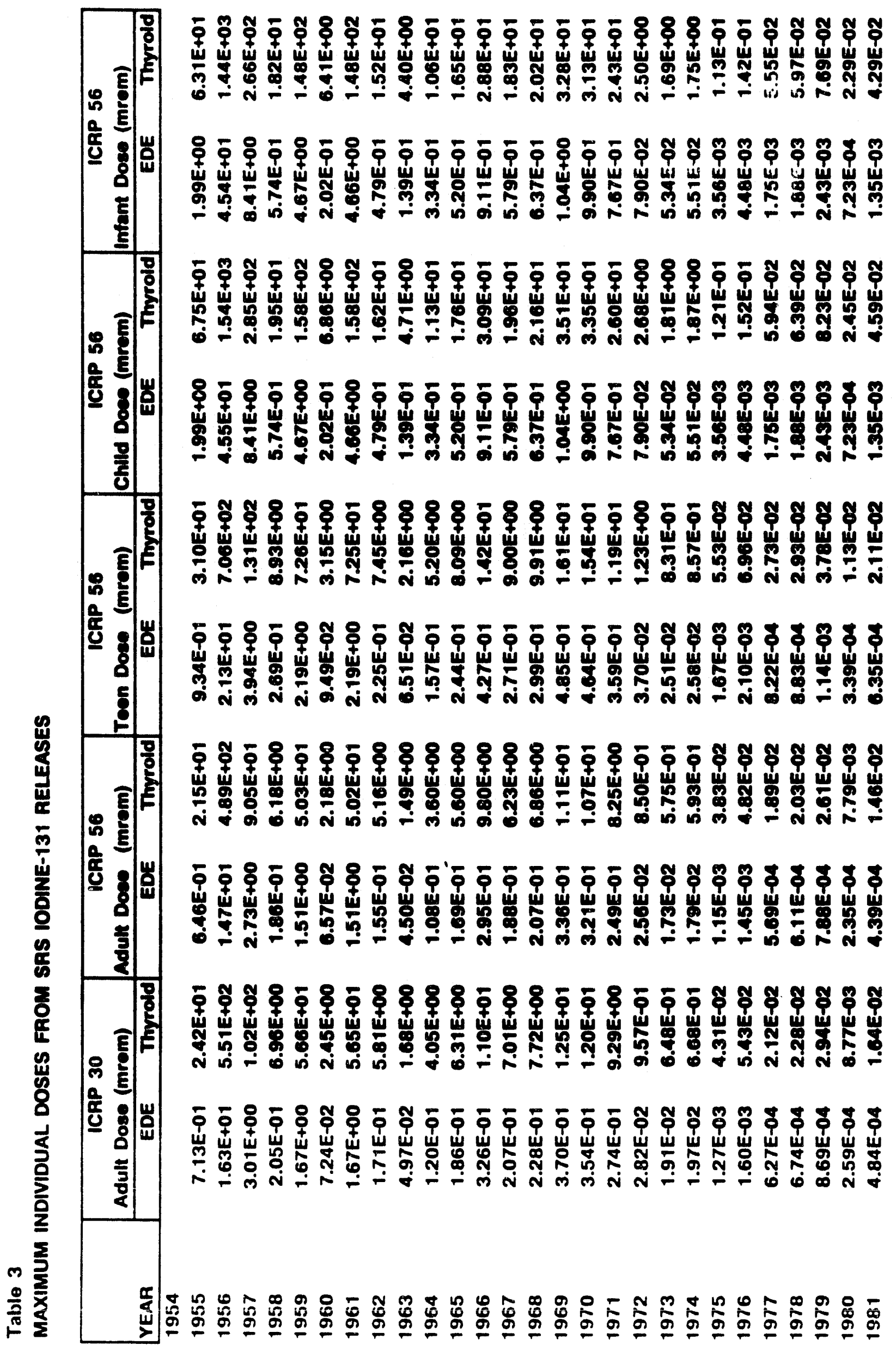














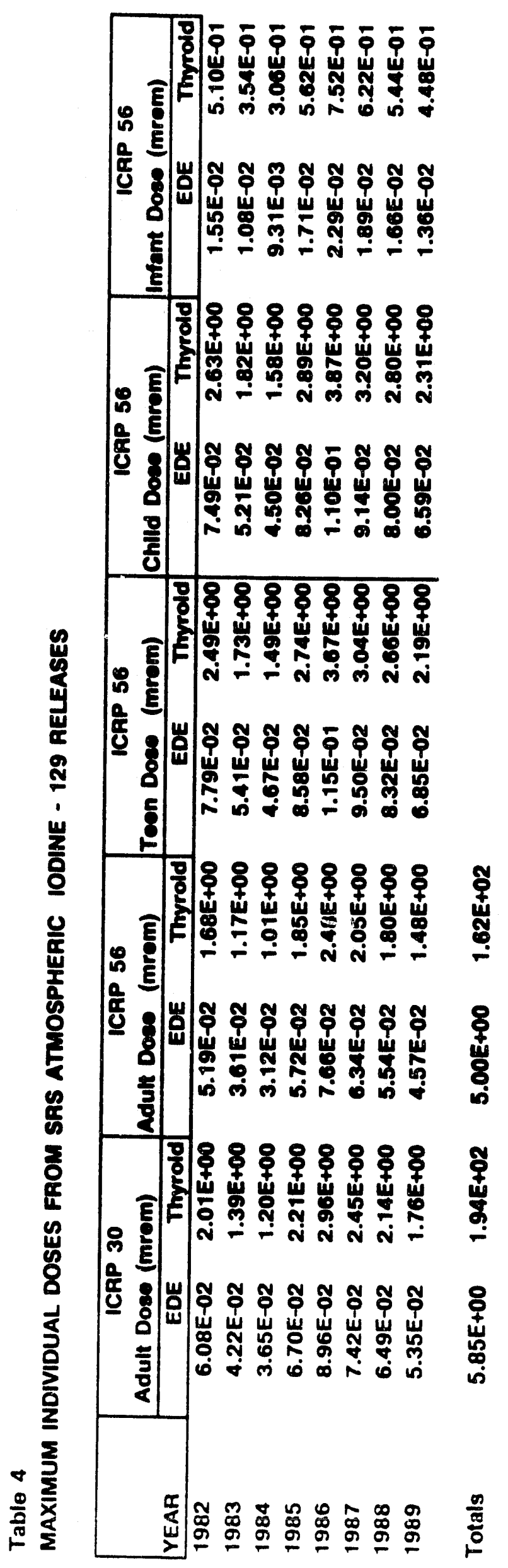


SRL-ETS-900317

Appendix A

\section{APPENDIXA. DOSE METHODOLOGIES}

\section{ROUTINE ATMOSPHERIC RELEASES}

Radioactive materials released to the atmosphere are transported, dispersed, and deposited by physical characteristics of moving atmospheric air masses. This transport and the physical and chemical characteristics of the material being transported are used to determine the fate of released radioactivity. Environmental models are then used to determine the entry of radioactive materials into the important exposure pathways to man. These pathways include direct, external exposure from the passing plume and deposits on the ground, and internal exposure from inhalation of air and food consumption. Models used in the calculation of doses from radioiodine included in this report are briefly described in the following sections. These models have been used for calculating the offsite impact of SRS routine radioactive releases since 1983 (Marter 1984).

Radioiodine Releases. Releases of radioiodines to the atmosphere used in this report are from historical records maintained since releases started in 1955. The data were obtained from a compilation of these releases issued by the Environmental and Health Protection Department (Hetrick 1990). Methods of monitoring radioiodine releases reflected monitoring technology at the time of the releases. No attempt was made in this report to determine the efficacy of the monitoring and analytical methods used.

Atmospheric Modeling. The transport of radioactive materials released to the atmosphere is calculated on the basis of local meteorological conditions. Meteorological conditions are continuously measured and recorded from seven onsite 200-ft towers and at a 1,200-ft television transmitting tower which is about 19 miles northwest of the center of the SRS. In this report, dose estimates were based on meteorological dispersion and deposition conditions measured over a five-year period (1982-86) at a meteorological tower located near the center of SRS (near H-Area). Data collected from the tower were used to prepare a joint-frequency table of wind speeds, wind directions, and stability categories for SRS. This meteorological joint-frequency table was used as input to a straight-line trajectory Gaussian plume model. This model accounts for the motion of the wind and the vertical and horizontal dispersion of the released radionuclides within the moving air mass and for the depletion of that mass by deposition and radioactive decay.

The dispersion-deposition model used at SRS for routine releases to the atmosphere is based on methods commonly used in the nuclear industry (NRC 1977a) and is implemented in the computer code XOQDOQ (Sagendorf 1982). This code calculates dispersion factors (called "chi over Q" or X/Q) and deposition factors (called "D over Q" or $D / Q$ ) at prescribed ground-level locations at various distances from the point of release. Figure A1 shows X/Q for the "worst-case" sector using 1982-1986 meteorological data (Laurinat 1987). For comparison, X/Q's are also shown for previous meteorological data bases, i.e., 1975-79 and 1966-68 (Cooper 1968 - this reference uses offsite television tower data). These data give us confidence that dispersion conditions do not change significantly over periods of time comparable to the operating lifetime of SRS. Measured annual average concentrations of tritium oxide in the atmosphere are compared with concentrations calculated with XOQDOQ (Marter 1984) and are published annually in SRS Environmental Reports. Generally, XOQDOQcalculated concentrations are conservative, i.e., calculations are higher than measured concentrations. Table Al shows a comparison of calculated and measured tritium oxide concentrations in air at the site perimeter. 
Dose Pathway Modeling For Routine Releases. After a radioactive material is dispersed in the environment, it may cause exposure of man through a number of pathways. In this report, the pathways considered from routine releases of radioiodines were external exposure from the passing plume, external exposure from deposits on the ground, and internal exposure from inhalation of air and consumption of locally-produced meat, milk, and vegetative food crops. These pathways are incorporated in the MAXIGASP computer code (Marter 1984) for calculating doses to the maximally exposed offsite individual. MAXIGASP is an SRL adaptation of the USNRC computer code, GASPAR (Eckerman 1980). The modifications to this code were those necessary to adapt the code to site-specific needs and parameters; the basic calculational methodologies were not modified. The methodologies used in this code are based on a model (NRC 1977b) widely used in the nuclear industry and is also used as the basis for computer codes developed by the Environmental Protection Agency for determining compliance with Clean Air Act regulations (i.e., AIRDOS-EPA Code, CAAC Code, and CAP88 Code).

The MAXIGASP Code incorporates a deterministic model, i.e., a single value is used for each input parameter to arrive at a predicted dose. These single values cannot reflect the influence of parameter variability. Stochastic models, on the other hand, can produce a range or distribution of predicted doses as a function of parameters which are variable. Since stochastic models are very complex and require many parameters that are either unknown or not well known, most environmental dosimetry models are deterministic. Parameter values for deterministic models are generally selected based on an average of data reported in the literature. SRL uses average parameter values recommended by NRC $1977 \mathrm{~b}$. Such average values may be significantly different from values best representing a specific situation. Thus, there is uncertainty if our deterministic model overestimates or underestimates doses. Empirically-derived parameters based on site-specific measurements are desirable for these models. However, most of the parameters applicable to local conditions are not available because insufficient measurements of food pathway relationships were made during the time that radioiodines were routinely measurable in the environment. In order to determine the possible range of doses that might occur, SRL is currently engaged in a long-range program of uncertainty analysis for the computer code used for the dose assessments in this report. It should be noted that most environmental models used in the United States and elsewhere are deterministic and suffer from these uncertainties including the EPA model used for determining compliance with Clean Air Act regulations.

A key parameter used in dose calculations is the average transfer factor of iodine from cow feed and forage to milk. The average value used in the MAXIGASP Code (and recommended in NRC 1977b) is 0.006 pCi/liter in milk per pCi ingested daily by cows. A site-specific value of about 0.004 pCi/hiter in milk per pCi ingested daily by cows can be derived from data collected following the 1961 I-131 release incident and during periods of I-131 deposition from weapons tests (Marter 1963). Thus, the MAXIGASP calculations of radioiodine dose from the milk pathway are believed to be conservative. Site-specific parameters relating transfer of iodine from soil to vegetation and from vegetation to animal meat have not been developed for SRS; average values recommended in NRC 1977 are used.

The MAXIGASP Code calculates the dose to the maximally exposed individual by using the assumption that the individual spends 100 percent of his time at the site perimeter at the location of maximum exposure. In addition, this individual consumes meat, milk, and vegetative crops produced at this same location. As a further conservatism, this 
individual is assumed to have a higher food consumption rate than an average incividual. No such person is known to exist and we believe that the dose calculated for this hypothetical individual is conservative.

Internal Dose Factors. The models and computer codes described in this appendix calculate the amount of human intake of radioactive materials by inialation and ingestion. These intakes are related to internal dose by use of internal dose factors. The methodology for developing internal dose factors has evolved as the technology has been refined. SRS environmental dosimetry computer codes have always used internal dose factors based on the most recently available recommendations of the International Commission on Radiological Protection. For more details, the reader is referred to ICRP 1960, ICRP 1978, and ICRP 1989. In the main body of this report, internal doses are calculated by these three different methodologies for comparison purposes. The most recent ICRP recommendations (ICRP 1989) are considered interim in nature for inhalation for age groups other than adults because interim parameters for inhalation are used for infants, children, and teenagers.

\section{IODINE-131 RELEASE INCIDENT}

About 153 curies of I-131 were released from a chemical processing plant at SRS during May 29-June 23, 1961 as the result of inadvertently processing some short-cooled fuel (Marter 1963). About 67\% (103 curies) of the I-131 was released during the first eight days. Prevailing southwest winds and atmospheric inversions dispersed the radioiodine mainly to the northeast of the plant. Iodine-131 was detectable in air, vegetation, and milk. This section describes how the maximum potential offsite dose was calculated with older methodologies and methods used for recalculating this dose with newer methodologies.

Original Dose Calculations. Following the 1961 release incident, thyroid doses were calculated for a maximum hypothetical adult and child from the milk pathway in the area of highest I-131 deposition detected by environmental monitoring.

For purposes of dose calculation, it was assumed that one liter of milk was consumed from each daily milking by an adult and a child until no I-131 remained in the milk. Thus, the integrated amount of I-131 ingested would be:

$$
\begin{aligned}
& Q \quad=q_{0} \int_{0}^{\infty} \exp ^{-\left(\lambda_{m} t\right)} d t \\
& \text { where } \\
& q_{0}=\text { initial intake rate, } p C i / d a y \\
& \lambda_{m}=\text { effective decay constant of } \mathrm{I}-131 \text { in milk, days }{ }^{-1} \\
& t=\text { length of time milk is ingested, days }
\end{aligned}
$$

For an infinite number of days of ingestion of milk, Eq. 1 becomes:

$$
\mathrm{Q}=\mathrm{q}_{\mathrm{o}} / \lambda_{\mathrm{m}}
$$


With an initial concentration of $\mathrm{I}-131$ in milk of $5451 \mathrm{pCi} / \mathrm{L}^{*}$, an assumed effectuve halftime of I-131 in milk of 8 days (actual measured half-time was 4 to 5 days), and a consumption rate of 1 liter per day, the total intake of I-131 would be:

$$
Q=\frac{(5451 \mathrm{pCi} / \mathrm{L})(1 \mathrm{~L} / \text { day })(8 \text { days })}{\ln 2}=62,913 \mathrm{pCi}
$$

The equation for relating intake to dose (based on ICRP 1960) is:

$$
D=\frac{(Q)(f)(\varepsilon)\left(3.7 \times 10^{-2}\right)\left(1.6 \times 10^{-6}\right)(1000) \int \exp ^{-\left(\lambda_{e} t\right)} d t}{100 \mathrm{~m}}
$$

where

$$
\begin{array}{ll}
\mathrm{D} & =\text { organ dose commitment, mrem } \\
\mathrm{Q} & =\text { integrated intake of radionuclide, } \mathrm{pCi} \\
\mathrm{f} & =\text { fraction of radionuclide reaching organ from ingestion }(0.3) \\
\varepsilon & =\text { effective energy per disintegration in organ, } \mathrm{MeV}(0.23) \\
3.7 \times 10^{-2} & =\text { disintegrations/second per } \mathrm{pCi} \\
1.6 \times 10^{-6} & =\text { ergs } / \mathrm{MeV} \\
1000 & =\text { mrem/rem } \\
100 & =\text { ergs/rem } \\
\mathrm{m} & =\text { mass of organ (thyroid adult }-20 \mathrm{~g}, \text { child } 2 \mathrm{~g}) \\
\lambda_{e} & =\text { effective decay constant in thyroid, } \sec ^{-1}\left(\text { for } \mathrm{T}_{1 / 2} \text { of } 7.6 \text { days, }=\right. \\
\mathrm{t} & \left.\quad 1.0556 \times 10^{-6} \text { sec }{ }^{-1}\right) \\
& =1.577 \times 10^{9} \mathrm{sec} \text { (i.e., } 50 \text { years) }
\end{array}
$$

which becomes:

$$
D=\frac{5.92 \times 10^{-7} \mathrm{Q} \text { f } \varepsilon\left(1-\exp \mathrm{p}^{-\left(1.557 \times 10^{9} \lambda_{e}\right)}\right)}{m \lambda_{e}}
$$
$\mathrm{pCi} /$ liter. Various reports have rounded this value to 5400 and $5500 \mathrm{pCi} /$ iter. Calculations in this report are based on a concentration of $5451 \mathrm{pCi} /$ /iter. 
For large values of $t$ relative to $\lambda_{e}$, the value in parentheses in Equation 5 becomes equal to 1.

Thus,

$$
D=\frac{5.92 \times 10^{-7} \mathrm{QfE}}{\mathrm{m} \mathrm{h}_{\mathrm{e}}}
$$

For the case of the maximum milk ingested by a child, the thyroid dose becomes:

$$
\begin{aligned}
& \mathrm{D}= \\
& \text { (child) }
\end{aligned} \frac{(5.92 \times 10-7)(62913)(0.3)(0.23)}{(2)\left(1.0556 \times 10^{-6}\right)}=1217 \mathrm{mrem}
$$

And the thyroid dose for an adult:

$$
\begin{aligned}
& \mathrm{D}= \\
& \text { (adult) } \\
& \cdots(20)\left(1.0556 \times 10^{-6}\right)
\end{aligned}=122 \mathrm{mrem}
$$

Dose With 5-Day Half-Time In Milk. Following the 1961 release incident, the halftime of I-131 in milk was determined to be 4 to 5 days by sequential milk sampling and analyses. The original dose calculations were made using an 8-day half-time for conservatism. If recalculated with 5 days, the integrated intake would be:

$$
Q=\frac{(5451 \mathrm{pCi} / \mathrm{L})(1 \mathrm{~L} / \text { day })(5 \text { days })}{\ln 2}=39321 \mathrm{pCi}
$$

Substituting this value in Equation 7 results in thyroid doses of $761 \mathrm{mrem}$ and $76 \mathrm{mrem}$ to a child and adult, respectively.

Doses from Other Pathways. During the week ending June 7, 1961, the average concentration of I-131 in air in the area of maximum offsite I-131 air concentration ranged from 1 to $5 \mathrm{pCi} / \mathrm{m}^{3}$ (Marter 1963). Immersion (plume) thyroid dose from one week of exposure to this contaminated air would be $4 \times 10^{-5}$ to $2 \times 10^{-4} \mathrm{mrem}$ (to a child or an adult) calculated with an immersion dose factor of $2.07 \times 10^{3} \mathrm{mrem} / \mathrm{year} \mathrm{per} \mu \mathrm{Ci} / \mathrm{m}^{3}$ (DOE 1988).

Breathing rates of $8000 \mathrm{~m}^{3} /$ year $\left(22 \mathrm{~m}^{3} /\right.$ day $)$ for adults and $3700 \mathrm{~m}^{3} /$ year $\left(10 \mathrm{~m}^{3} /\right.$ day $)$ for children (NRC 1977) were used to calculate the amounts of I-131 inhaled. These amounts are shown with resultant thyroid doses calculated with Equation 6 in the following table: 


\section{Thyroid Doses (Based on Equation 6)}

$\begin{array}{lll}\text { Age } & \begin{array}{l}\text { Amount } \\ \text { inhaled } \mathrm{DCj}\end{array} & \begin{array}{l}\text { Thyroid } \\ \text { dose. mrem }\end{array} \\ \text { child } & 71-355 & 1.4-6.9 \\ \text { adult } & 153-767 & 0.3-1.5\end{array}$

The average concentration of I-131 in eggs (from the farm with the highest milk concentration) was $33 \mathrm{pCi}$ per egg (Marter 1963). At a consumption rate of 2 eggs per day and an assumed 5-day half-time in eggs, the integral intake from Equation 2 would be $476 \mathrm{pCi}$. The dose from this intake by a child and an adult would be 7.1 and 0.7 mrem, respectively (calculated with Equation 6). The only other perishable food of dietary significance available in early June was peaches. No evidence of I-131 contamination was found in peaches.

From the foregoing discussion of I-131 doses from other pathways, it appears that greater than $95 \%$ of the total thyroid dose for a child would have resulted from the milk pathway.

Dose With More Recent Models. Since 1984 (Marter 1984), SRL has calculated offsite doses based on USNRC Regulatory Guide 1.109 (NRC 1977). This Guide recommends the following values as typical for daily intake of milk by maximum individuals:

$\begin{array}{lll}\text { Age } & \begin{array}{l}\text { Annual milk } \\ \text { intake. liters }\end{array} & \begin{array}{l}\text { Daily milk } \\ \text { intake. liters }\end{array} \\ \text { infant } & 330 & 0.904 \\ \text { child } & 330 & 0.904 \\ \text { teen } & 400 & 1.096 \\ \text { adult } & 310 & 0.849\end{array}$

From Equation 2 and a 5-day half-time in milk, the integral intake of I-131 was calculated:

$\begin{array}{ll}\text { Age } & \begin{array}{l}\text { Integral intake, } \\ \text { DCi }\end{array} \\ \text { infant } & 35,546 \\ \text { child } & 35,546 \\ \text { teen } & 43,095 \\ \text { adult } & 33,383\end{array}$

These integral intakes can be related to thyroid dose by the use of internal dose factors. Dose factors The following table compares the thyroid dose factors for ingestion of I-13I from these three publications. It should be noted that dose factors were provided only for adults in ICRP Publication 30. Changes from the earliest to the most recent publications reflect increasing knowledge of the biokinetics of radionuclides in the body and improved dosimetry models. 


\section{-131 Thyroid Ingestion Dose Factors, mrem/pCi*}

\begin{tabular}{|c|c|c|c|}
\hline $\begin{array}{l}\text { Age } \\
\text { infant }\end{array}$ & $\frac{\operatorname{ICRP} 2}{1.39 \times 10^{-2}}(0-1)$ & $\frac{\text { ICRP } 30}{\text { NA }}$ & $\frac{\text { ICRP 56 }}{1.4 \times 10^{-2}(0-1)}$ \\
\hline child & $5.72 \times 10^{-3}(1-11)$ & NA & $7.8 \times 10^{-3}(2-7)$ \\
\hline teen & $2.39 \times 10^{-3}(11-17)$ & NA & $2.6 \times 10^{-3}(12-17)$ \\
\hline & $1.95 \times 10^{-3}(>17)$ & $1.80 \times 10^{-3}(>17)$ & $1.6 \times 10^{-3}(>17)$ \\
\hline
\end{tabular}

* Numbers in parentheses are ages in years.

Using these dose factors and the integral I-131 intake shown above, the following maximum thyroid doses were calculated for the 1961 I-131 release incident:

Thyroid Dose from J13 L in milk mrem

$\begin{array}{llll}\text { Age } & \text { ICRP 2 } & \text { ICRP 30 } & \text { ICRP 56 } \\ \text { infant } & 494(0-1) & \text { NA } & 497(0-1) \\ & & & 462(1-2) \\ \text { child } & 203(1-11) & \text { NA } & 277(2-7) \\ & & & 252(7-12) \\ \text { teen } & 103(11-17) & \text { NA } & 112(12-17) \\ \text { adult } & 65(>17) & 60(>17) & 53(>17)\end{array}$


SRL-ETS-900317

Appendix A

\section{REFERENCES-APPENDXX}

Cooper, R.E. and B.C. Rusche, 1968. The SRL Meteorological Program and Off-Site Dose Calculations. DP-1163, Savannah River Laboratory.

DOE, 1988. External Dose-Rate Conversion Factors for Calculation of Dose to the Public. DOE/EH-0070, U.S. Department of Energy.

Eckerman, K.F., F.J. Congel, A.K. Roecklein, and W.J. Pasciak, 1980. User's Guide to GASPAR Code. NUREG-0597, U.S. Nuclear Regulatory Commission.

Hetrick, C.S. and D.K. Martin, 1990. Radioactive Releases at the Savannah River Site 1954-1988. WSRC-RP-89-737, Westinghouse Savannah River Company.

Hoenes, G.R. and J.K. Soldat, 1977. Age-Specific Radiation Dose Commitment Factors for a Chronic One-Year Intake. NUREG-0172, Battelle Pacific Northwest Laboratories for the U.S. Nuclear Regulatory Commission (based on ICRP 1960).

ICRP, 1960. Report of ICRP Committee II on Permissible Dose for Internal Radiation (1959). ICRP Publication 2, International Commission on Radiological Protection.

ICRP, 1978. Limits for Intakes of Radionuclides by Workers. ICRP Publication 30, Annals of the ICRP, International Commission on Radiological Protection.

ICRP, 1989. Age-Dependent Doses to Members of the Public from Intake of Radionuclides. ICRP Publication 56, Annals of the ICRP, International Commission on Radiological Protection.

Laurinat, J.E., 1987. Average Wind Statistics for SRP Area Meteorological Towers. DPST-87-341, Savannah River Laboratory.

Marter, W.L., 1963. Radioiodine Release Incident at the Savannah River Plant. Health Physics, Vol. 9, pp 1105-1109.

Marter, W.L., 1984. Environmental Dosimetry for Normal Operations at SRP. DPST-83270, Rev. 1, Savannah River Laboratory.

NRC, 1977a. Methods for Estimaning Atmospheric Transport and Dispersion of Gaseous Effluents in Routine Releases from Light-Water-Cooled Reactors. Regulatory Guide 1.111, Rev. 1, U.S. Nuclear Regulatory Commission.

NRC, 1977b. Calculation of Annual Doses to Man from Routine Releases of Reactor Effluents for the Purpose of Evaluating Compliance with 10 CFR Part 50, Appendix I. Regulatory Guide 1.109, U.S. Nuclear Regulatory Commission.

Sagendorf, J.F., J.T. Goll, and W.F Sandusky, 1982. XOQDOQ: Computer Program for Meteorological Evaluation of Routine Effluent Releases at Nuclear Power Stations. NUREG/CR-2919, U.S. Nuclear Regulatory Commission. 
Table A1

COMPARISON OF CALCULATED AND MEASURED ANNUAL AVERAGE TRITIUM CONCENTRATIONS AT THE SITE PERIMETER

Year

1986

1987

1988

1980
Tritium Oxide Concentration, pCl/cu m

Calculated Measured

120

70

81

84

37
Ratio:Calc/Mans

1.8

1.1

1.0

1.8

1.8 


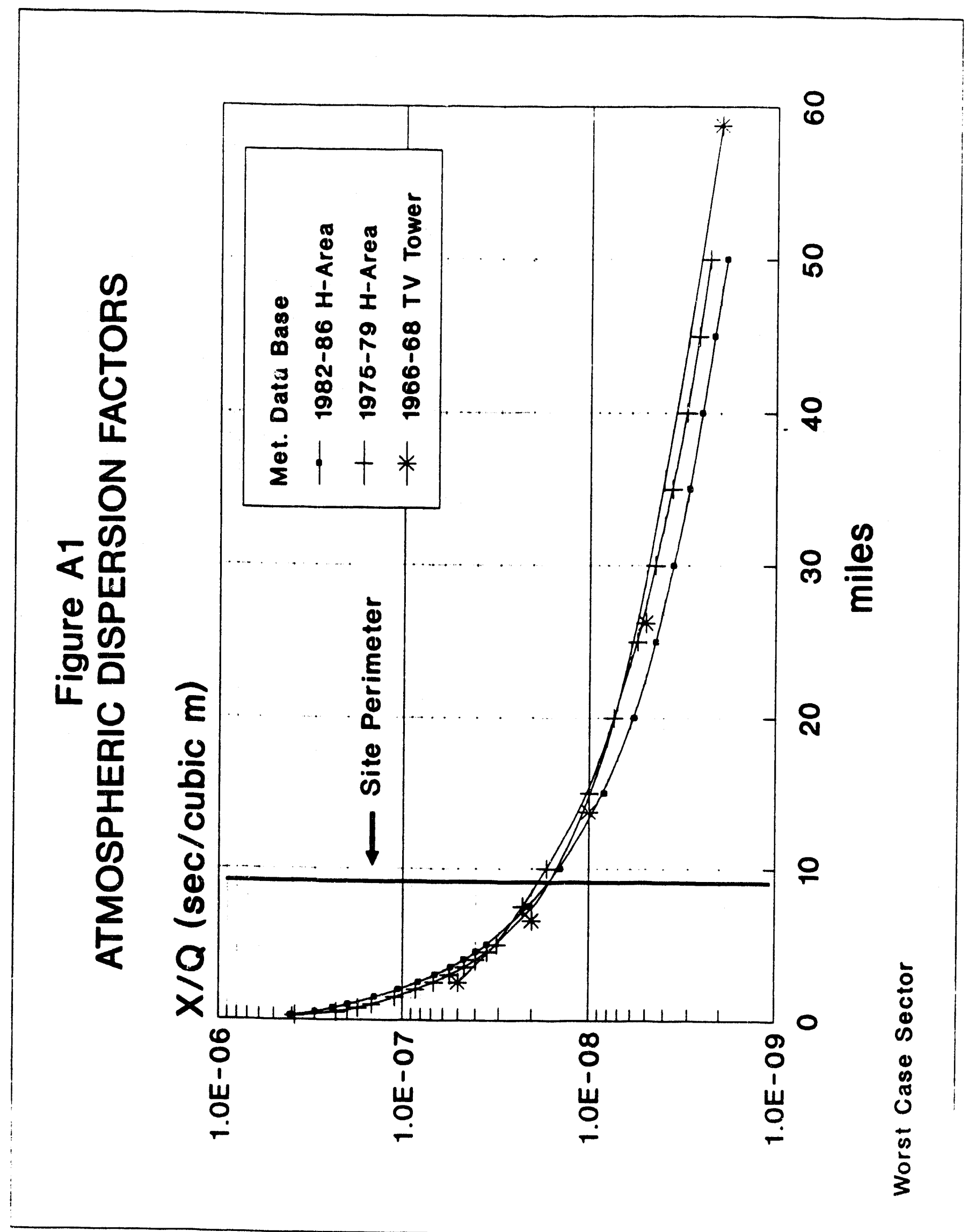


SRL-ETS-900317

Appendix B

\section{APPENDIX B - THYROID DOSE AND BIOLOGICAL EFFECTS}

\section{RADIOIODINE EXPOSURE AND DOSE TO MAN}

Naturally occurring iodine (iodine-127) is an essential microconstituent in the human body, which contains an average of 11 milligrams of the element. of which. 11 milligrams is in the thyroid gland (adult). The thyroid is an endocrine gland in the throat below the larynx. The thyroid secretes iodine-bearing hormones, especially thyroxine, which are essential for maintaining normal metabolism in all body cells.

Radioisotopes of iodine have the same biochemical behavior in the human body as naturally occurring iodine, i.e., a large fraction of intake is concentrated in the thyroid gland.

Radioiodine isotopes released to the environment from nuclear industry and weapons test fallout can exist in a variety of chemical forms, i.e., $\mathbf{2}_{2}, \mathrm{HI}$, and various organic forms. After transport in the environment, radioiodines may expose man by inhalation and by ingestion of food and water. The International Commission on Radiological Protection (ICRP 1979; ICRP 1989) uses a Gastrointestinal (GI) Tract uptake fraction $\left(f_{1}\right)$ of 1 for ingestion of all commonly occurring compounds of iodine based on experiments with mice, rats, dogs, and sheep (Willard 1961; Bair 1963).

\section{DISTRIBUTION AND RETENTION OF IODINE IN THE HUMAN BODY}

Essentially all of the iodine (including radioisotopes of iodine) that enters the lungs and the gastrointestinal tract is rapidly absorbed in body fluids. In all age groups, with the exception of newborn infants up to 5 days, the fractional uptake by the thyroid is 0.3 . Fractional uptake by the thyroid gland of newborn infants is about 0.7 , declining to values at or below that observed for adults by five days after birth (ICRP 1989).

lodine which does not locate in the thyroid is assumed to go directly to excretion (ICRP 1979). Organic iodine reentering the blood from the thyroid in the form of hormones is metabolized in tissues and is returned to the plasma pool as inorganic iodide. Thus, some iodine will be recycled to the thyroid. About $20 \%$ of the organic iodine is excreted in the feces. Most of the inorganic iodine is excreted in the urine (ICRP 1989).

The turnover rate (depletion) of natural iodine in the thyroid gland and the rest of the body decreases with increasing age as shown in Table B1. These biokinetic data are used in the ICRP model (ICRP 1989) for calculating age-dependent internal doses from the radioiodines. Also shown in Table B1 are standardized thyroid and body masses for the various age groups.

The "effective" half-life of iodine radioisotopes in the thyroid are a function of the biological half-life and radiological half-life. Effective half-life can be calculated with the following expression:

$$
\mathrm{Te}=(\mathrm{Tr} \mathrm{Tb}) /(\mathrm{Tr}+\mathrm{Tb})
$$


where

$$
\begin{aligned}
& \mathrm{Te}=\text { effective half-life, days } \\
& \mathrm{Tr}=\text { radiological half-life, days } \\
& \mathrm{Tb}=\text { biological half-life, days }
\end{aligned}
$$

In the case of iodine-131 in the adult thyroid with a radiological half-life of 8.04 days and a biological half-life of 80 days (adult), the effective half-life would be:

$$
\text { Te-adult }=(8.04 \times 80) /(8.04+80)=7.31 \text { days }
$$

Using the same method of calculation, the effective half-life of iodine-131 in the thyroid of the various age groups are: 3 mos - 4.64 days, 1 year - 5.23 days, 5 years - 5.96 days, 10 years -7.06 days, and 15 years -7.18 days.

\section{DOSIMETRY}

As stated previously, the inhalation and ingestion of all common compounds of radioiodines results in $100 \%$ transfer into the blood. Approximately $30 \%$ of the intake of radioiodine locates in the thyroid gland in all age groups except newborn infants. The ICRP (ICRP 1989) has adopted a three compartment model to describe the biokinetics of iodine after entry into the blood. The compartments are 1) blood, 2) thyroid, and 3) rest of body. This model allows for recycling of radioiodine released from the thyroid in the form of organic iodine compounds (hormones). The consideration of recycling is only necessary for long-lived isotopes of iodine. Because iodine is recycled through the thyroid, monitoring the gland after an intake of radioiodine will not reveal a single exponential clearance, but would be approximately described by the sum of two exponentials.

$$
R(t) \quad=\quad A e-0.693 t / T 1+(1-A) e-0.693 t / T 2
$$

where

$$
\begin{aligned}
& R(t) \quad=\quad \text { fractional retention in the thyroid gland } \\
& \mathrm{T} 1 \text { and } \mathrm{T} 2=\text { observed half-times }
\end{aligned}
$$

Retention data were largely determined using iodine-131, whose radiological half-life (8.04 days) is too short to observe a two-exponential clearance. A mean apparent half-time for adults of 91 days was adopted by the ICRP (ICRP 1989) for dosimetric purposes. Values for other age groups are: 3 mos - 15 days, 1 year - 20 days, 5 years - 30 days, 10 years - 70 days, and 15 years - 80 days. These apparent half-times were used to calculate the biological half-lives shown in Table B1. In previous ICRP internal dose calculations (ICRP 1979), a biological half-life of iodine in the adult thyroid of 120 days was used versus the more recent value of 80 days in Table B1. Department of Energy internal dose factors (DOE 1988) calculated by the ICRP 1979 methodology are compared with the newer ICRP 1989 values in "'able B2.

ICRP 1989 limited its consideration of age-dependent dose factors to the most radiologically significant isotopes that might be released to the environment due to various human activities. Thus, age-dependent ICRP 1989 dose factor values were only provided for three radioisotopes of iodine, i.e., iodine-129, 131, and 132. The earlier DOE 1988 dose factors, which were limited to adults, included all iodine radioisotopes with radiological half-lives long enough to result in a significant internal dose.

The ICRP 1989 internal dose factors for adults in Table B2 are lower than comparable 
DOE 1988 dose factors. This difference is caused by the shorter biological half-life used in ICRP 1989. The differences are small for isotopes with short radiological half-lives (iodine-131 (8.04 days) and iodine-132 (2.3 hours)) but is more significant for the longlived iodine-129 (1.57 $\times 10$ years)).

The ICRP is currently developing an age-dependent lung model for inhalation doses. This model is not yet available and the lung model used in ICRP 1979 was used für calculating ICRP 1989 inhalation dose factors shown in Table B2. The lung model used does not make any allowance for age-dependent changes in deposition or clearance of inhaled material. Therefore, the age-dependent inhalation dose factors in Table B2 are considered to be interim.

\section{RADIATION CARCINOGENESIS OF THE THYROID GLAND (BEIR 1990)}

The possible radiological damage to the thyroid gland from human exposure to radioiodines can manifest itself in the form of immediate physical damage (cell killing from very high doses) and an increased incidence of thyroid cancer. Doses high enough to cause immediate physical damage would be rarely encountered except in the intentional administration of radioiodine by medical practitioners for therapeutic purposes. Of more concern are radiogenic thyroid abnormalities that might be associated with unusual environmental exposure from inhalation and ingestion of food and water.

The increased incidence of thyroid cancer from ionizing radiation has been observed in a number of groups, including infants exposed to therapeutic x-rays, Japanese atomic bomb survivors, and Marshall Islanders exposed to radioactive fallout. Studies of these groups indicate that the greatest susceptibility to radiation-induced thyroid cancer occurs during infancy and early childhood during the first five years of life. In those exposed before puberty, the tumors usually do not become apparent until after sexual maturation. The risk of radiation-induced cancer in adults is only one-half, or less, of that in children. Females are roughly 3 times more sensitive than males to radiogenic, as well as nonradiogenic (background) thyroid cancer.

Iodine-131 has been commonly used in the past in diagnostic procedures used in thyroid function tests. In one large study of 35,000 people undergoing such tests, the mean thyroid dose was $50 \mathrm{rad}$. The results of this study indicates that diagnestic doses of I-131 do not significantly increase the risk of thyroid cancer.

Accepted criteria for definition of various types of thyroid neoplasms" have been developed and promulgated by the World Health Organization. This classification divides thyroid cancer into follicular, papillary, squamous-cell, undifferentiated (anaplastic), and medullary types. Medical studies have indicated that radiogenic thyroid cancers are generally papillary growths; relatively few are follicular or mixed pathology. This type of thyroid cancer causes death in only about $10 \%$ of all cases. The more malignant types of thyroid cancers have not been found to have a radiogenic origin.

* Neoplasms. Any new and abnormal growth such as a tumor; neoplastic disease refers to any disease that forms tumors, whether malignant or benign. 


\section{REFERENCES - APPENDIX B}

Bair, W.J., Snyder, M.D., Walters, R.A. and Keough, R.F., 1963. Effect of lodine-127 on Thyroid Uptake of Inhaled Iodine-131. Health Phys.9, 1399-1410.

BEIR, 1990. Health Effects of Exposure to Low Levels of Ionizing Radiution - BEIR V. Committee on the Biological Effects of Ionizing Radianons, Board un Radiation Effects Research, Commission on Life Sciences, National Research Council, National Academy of Science.

DOE (Department of Energy), 1988. Internal Dose Conversion Factors for Calculation of Dose to the Public, DOE/EK-007.

ICRP (International Commission on Radiological Protection), 1979. Limits for Intake Radionuclides by Workers, ICRP Publication 30, Part 1, Annals of the ICRP.

ICRP (International Commission on Radiological Protection), 1989. Age-Dependent Doses to Members of the Public from Radionuclides, ICRP Publication 56, Annals of the ICRP.

Willard, D.H and Bair, W.J., 1961. Behavior of Iodine-131 following its Inhalation as a Vapor and as a Particle, Acta Radiol. 55, 486-496. 
Table B1. BIOKINETIC AND ORGAN MASS DATA FOR IODINE DOSE CALCULATIONS

\begin{tabular}{|c|c|c|c|c|c|}
\hline \multirow[b]{2}{*}{ Age } & \multirow{2}{*}{$\begin{array}{l}\text { Fractional } \\
\text { Uptake by } \\
\text { Thyroid }\end{array}$} & \multicolumn{2}{|c|}{$\begin{array}{l}\text { Biological } \\
\text { Half-Life, days }\end{array}$} & \multicolumn{2}{|c|}{ Organ Mass, $\mathbf{g}$} \\
\hline & & Thyroid & Body & Thyroid & Bodv \\
\hline $3 \mathrm{mos}$ & 0.3 & 11.2 & 1.12 & 1.29 & 6000 \\
\hline $1 \mathrm{yr}$ & 0.3 & 15.0 & 1.50 & 1.78 & 9800 \\
\hline 5 yrs & 0.3 & 23.0 & 2.30 & 3.45 & 19000 \\
\hline $10 \mathrm{yrs}$ & 0.3 & 58.0 & 5.80 & 7.93 & 32000 \\
\hline 15 yrs & 0.3 & 67.0 & 6.70 & 12.40 & 55000 \\
\hline Adult & 0.3 & 80.0 & 12.00 & 20.00 & 70000 \\
\hline
\end{tabular}


Table B2. INTERNAL DOSE FACTORS FOR IODINE ISOTOPES

\begin{tabular}{|c|c|c|c|c|c|c|c|c|}
\hline \multirow[b]{2}{*}{ Isotope } & \multirow[b]{2}{*}{$\begin{array}{l}\text { Half } \\
\text { Life }\end{array}$} & \multirow[b]{2}{*}{$\begin{array}{r}\text { Age } \\
\text { Group }\end{array}$} & \multirow[b]{2}{*}{$\begin{array}{l}\text { Intake } \\
\text { Mode }\end{array}$} & \multicolumn{4}{|c|}{ Dese Factor, mrem/pCl } & \multirow[b]{2}{*}{$\begin{array}{l}\text { Date } \\
\text { Source }\end{array}$} \\
\hline & & & & $\begin{array}{r}\text { Effect. } \\
\text { D.Equiv. }\end{array}$ & $\begin{array}{r}\text { Stomach } \\
\text { Wall } \\
\end{array}$ & Thyroid & Lungs & \\
\hline \multirow[t]{2}{*}{ I-120M } & $53 m$ & sdult & ingest. & $3.9 E-07$ & $4.1 E-06$ & $4.8 E-06$ & $-\infty$ & DCE1088 \\
\hline & & adult & Inhal. & $2.2 E-07$ & $5.2 E-07$ & $2.1 E-00$ & $1.1 E-08$ & DOE1988 \\
\hline \multirow[t]{2}{*}{$1-120$} & $81 \mathrm{~m}$ & adult & ingest. & 6.7E-07 & $4.8 E-06$ & $1.3 E-05$ & - & DOE1988 \\
\hline & & adult & Inhal. & 4.1E-07 & 6.3E-07 & $5.0 E-00$ & $1.6 E-06$ & DOE1988 \\
\hline \multirow[t]{2}{*}{$\mid-121$} & $2.12 h$ & adult & ingest. & $1.8 E-07$ & $4.1 E-07$ & $5.2 E-08$ & - & DOE1988 \\
\hline & & adult & inhal. & $1.0 E-07$ & - & $2.8 E-06$ & 1.7E-07 & COE1988 \\
\hline \multirow[t]{2}{*}{ |.123 } & $13.2 \mathrm{~h}$ & adult & ingest. & $4.0 E-07$ & - & $1.6 E-05$ & - & DOE1988 \\
\hline & & adult & Inhal. & 2.7E-07 & - & $8.1 E-\infty 8$ & 2.4E-07 & DOE19s8 \\
\hline \multirow[t]{2}{*}{$\mid-124$} & $4.18 d$ & adult & ingest. & $3.1 E-05$ & - & $1.0 E-03$ & - & DOE1988 \\
\hline & & sdult & Inhal. & $1.0 E-05$ & - & 6.3E-O4 & - & DOEigas \\
\hline \multirow[t]{2}{*}{$1-125$} & $60.14 d$ & adult & Ingest. & $3.8 E-05$ & - & $1.3 E-03$ & - & DoE1988 \\
\hline & & adult & Inhal. & 2.4E-05 & - & $8.1 E-04$ & - & DOE1988 \\
\hline \multirow[t]{2}{*}{$1-126$} & $13.02 d$ & adult & ingest. & 7.1E-05 & - & 2.4E-03 & - & DoE1ces \\
\hline & & adun & Inhal. & 4.3E-0.5 & - & $1.4 E-03$ & - & DoE1ees \\
\hline \multirow[t]{2}{*}{$1-128$} & $24.90 \mathrm{~m}$ & aduit & ingest. & 8.5E-08 & $1.2 E-08$ & $4.1 E-04$ & - & DoE1898 \\
\hline & & odult & inhal. & 4.5E-08 & $1.2 E-07$ & $2.0 E-07$ & 2.7E-07 & DOE19e8 \\
\hline \multirow[t]{14}{*}{$\mid-120$} & $1.57 E 7 y$ & $3 \mathrm{mos}$ & Ingeat. & 4.1E-04 & 4.4E-06 & 1.4E-02 & - & ICRP19s0 \\
\hline & & $1 \mathrm{yr}$ & ingest. & 4.8E-04 & $2.6 E-08$ & $1.6 E-02$ & - & ICRP1980 \\
\hline & & 5 yrs & Ingest. & 3.7E-04 & $1.4 E-08$ & $1.3 E-02$ & - & ICAP 1890 \\
\hline & & $10 \mathrm{yrs}$ & ingest. & $4.1 E-04$ & $1.0 E-08$ & $1.4 E-02$ & - & ICRP18so \\
\hline & & 15 yrs & ingest. & $3.1 E-04$ & $7.0 E-07$ & $1.0 E-02$ & - & ICRP1890 \\
\hline & & adull & ingest. & 2.4E-04 & 7.4E-07 & $7.8 E-03$ & - & ICRP1889 \\
\hline & & adutt & ingest. & 2.8E-04 & - & $9.3 E-03$ & - & DOE18a8 \\
\hline & & 3 mos & Inhal. & $2.6 E-04$ & $1.1 E-06$ & 8.5E-03 & 8.1E-07 & ICRP 1980 \\
\hline & & $1 \mathrm{yt}$ & inhal. & $3.0 E-04$ & $6.7 E-07$ & $1.0 E-02$ & $1.3 E-08$ & ICRP1980 \\
\hline & & 5 yrs & inhal. & 2.4E-04 & 4.1E-07 & 8.1E-03 & 7.8E-07 & ICAP1880 \\
\hline & & $10 \mathrm{yrs}$ & inhal. & 2.7E-04 & 3.7E-07 & $8.0 E-03$ & $8.5 E-07$ & ICRP1980 \\
\hline & & $15 \mathrm{yrs}$ & inhal. & $2.0 E-04$ & $2 . e E-07$ & $6.7 E-03$ & $4.8 E-07$ & ICRP1890 \\
\hline & & adult & inhal. & $1.5 E-04$ & $3.1 E-07$ & $4.8 E-03$ & $5.9 E-07$ & ICRP1990 \\
\hline & & aduln & inhal. & $1.8 E-04$ & - & $5.9 E-03$ & - & DOE19e8 \\
\hline \multirow[t]{2}{*}{$1-130$} & $12.36 \mathrm{~h}$ & adult & ingeet. & $4.3 E-06$ & - & $1.4 E-04$ & - & DOE1Ca8 \\
\hline & & adult & inhol. & $2.5 E-06$ & - & 7.4E-05 & 2.2E-08 & DOE19s8 \\
\hline \multirow[t]{7}{*}{$1-131$} & $8.04 \mathrm{~d}$ & $3 \mathrm{mos}$ & ingest. & 4.1E-04 & 1.3E-05 & $1.4 E-02$ & - & ICAP1880 \\
\hline & & $1 \mathrm{yr}$ & ingest. & 4.1E-04 & 7.4E-06 & $1.3 E-02$ & - & ICRP 1880 \\
\hline & & 5 yrs & ingest. & 2.3E-04 & $3.6 E-06$ & $7.8 E-03$ & - & ICRP 1989 \\
\hline & & $10 y r s$ & ingest. & $1.2 E-04$ & 2.1E-08 & 4.1E=-03 & - & ICRP 1980 \\
\hline & & 15 yrs & ingest. & 7.8E-05 & $1.4 E-06$ & 2.6E-03 & - & ICRP 1980 \\
\hline & & adutt & ingest. & $4.8 E-05$ & 1.1E-06 & $1.6 E-03$ & - & ICRP 1989 \\
\hline & & adult & ingest. & 5.3E-05 & - & 1.8E-03 & - & DOE 1988 \\
\hline
\end{tabular}


Table B2. INTERNAL DOSE FACTORS FOR IODINE ISOTOPES

\begin{tabular}{|c|c|c|c|c|c|c|c|c|}
\hline \multirow[b]{2}{*}{ Isotope } & \multirow[b]{2}{*}{$\begin{array}{l}\text { Half } \\
\text { Llife } \\
\end{array}$} & \multirow[b]{2}{*}{$\begin{array}{r}\text { Age } \\
\text { Group } \\
\end{array}$} & \multirow[b]{2}{*}{$\begin{array}{l}\text { Intake } \\
\text { Mode }\end{array}$} & \multicolumn{4}{|c|}{ Dose Factor, mrem/pCl } & \multirow[b]{2}{*}{$\begin{array}{l}\text { Date } \\
\text { Source }\end{array}$} \\
\hline & & & & $\begin{array}{l}\text { Effect. } \\
\text { D.Equiv. }\end{array}$ & $\begin{array}{r}\text { Stomach } \\
\text { Wall } \\
\end{array}$ & Thyroid & Lungs & \\
\hline \multirow[t]{7}{*}{$1-131$} & $8.04 d$ & $3 \mathrm{mos}$ & inhal. & $2.6 E-04$ & $2.8 E-06$ & $8.5 E-03$ & $3.3 E-08$ & ICAP 1980 \\
\hline & & $1 \mathbf{y r}$ & Inhal. & 2.5E-04 & $1.7 E-08$ & $8.1 E-03$ & $2.4 E-06$ & ICRP 1889 \\
\hline & & 5 yrs & inhal. & $1.4 E-04$ & $8.9 E-07$ & $4.8 E-03$ & $1.4 E-06$ & ICRP 1980 \\
\hline & & $10 \mathrm{yrs}$ & Inhal. & $7.4 E-05$ & $5.2 E-07$ & $2.4 E-03$ & 8.9E-07 & ICRP 1880 \\
\hline & & 15 yrs & Inhal. & $4.8 E-05$ & $3.4 E-07$ & $1.6 E-03$ & $5.2 E-07$ & ICRP 1980 \\
\hline & & adult & Inhal. & $3.0 E-05$ & $2.6 E-07$ & $1.0 E-03$ & 4.4E-07 & ICRP1980 \\
\hline & & adult & Inhal. & $3.2 E-05$ & - & $1.1 E-03$ & - & DOE19es \\
\hline \multirow[t]{2}{*}{$1-132 M$} & $83.6 \mathrm{~m}$ & adult & Ingeet. & 4.7E-07 & $1.0 E-08$ & $1.4 E-05$ & - & DOE1989 \\
\hline & & adult & inhal. & $2.6 E-07$ & $2.0 E-07$ & $5.0 E-08$ & 6.7E-04 & DOE1988 \\
\hline \multirow[t]{14}{*}{$1-132$} & $2.3 h$ & $3 \mathrm{mos}$ & Ingeat. & $7.0 E-08$ & $2.5 E-05$ & $1.5 E-04$ & - & ICRP1989 \\
\hline & & $1 y$ & ingeet. & $5.6 E-06$ & 1.4E-05 & $1.3 E-04$ & - & ICAP1980 \\
\hline & & 5 yrs & ingest. & $2.8 E-08$ & 7.0E-06 & $7.0 E-05$ & - & ICRP 1889 \\
\hline & & 10 yrs & Ingest. & $1.4 E-06$ & 4.1E-06 & 3.1E-05 & - & ICRP 1980 \\
\hline & & $15 \mathrm{yrs}$ & ingeat. & $0.3 E-07$ & $3.0 E-08$ & 2.1E-05 & - & ICRP 1989 \\
\hline & & aduk & ingest. & 6.3E-07 & $2.3 E-08$ & 1.3E-05 & - & ICRP 1980 \\
\hline & & aduht & ingest. & $1.0 E-08$ & $2.3 E-08$ & $1.4 E-05$ & - & DOE1989 \\
\hline & & 3 mos & inhal. & $3.7 E-06$ & 3.7E-06 & 6.7E-05 & $1.1 E-08$ & ICRP18s0 \\
\hline & & $1 \mathrm{yr}$ & Inhal. & $3.0 E-06$ & 2.1E-06 & 5.9E-05 & 7.4E-07 & ICRP IOSO \\
\hline & & 5 yrs & Inhal. & $1.6 E-06$ & $1.1 E-08$ & $3.2 E-05$ & $3.7 E-07$ & ICRP 1980 \\
\hline & & $10 \mathrm{yrs}$ & inhal. & 8.1E-07 & 6.7E-07 & $1.4 E-05$ & $2.5 E-07$ & ICRP 1980 \\
\hline & & $15 \mathrm{yrs}$ & Inhal. & $5.6 \varepsilon-07$ & 4.4E-07 & $0.3 E-\infty 8$ & $1.6 E-07$ & ICAP 1980 \\
\hline & & aduls & Inhal. & $3.7 E-07$ & $3.6 E-07$ & $5.9 E-\infty 6$ & $1.3 E-07$ & ICRP 1880 \\
\hline & & & Inhal. & $3.3 E-07$ & $3.7 E-07$ & $6.3 E-06$ & $1.0 E-06$ & DOE1988 \\
\hline \multirow[t]{2}{*}{$\mid-133$} & $20.8 \mathrm{~h}$ & adult & Ingest. & $1.0 E-05$ & - & 3.4E-04 & - & DOE1988 \\
\hline & & & inhal. & $5.4 E-08$ & - & $1.8 E-04$ & - & DOE1988 \\
\hline \multirow[t]{2}{*}{$1-134$} & $52.6 \mathrm{~m}$ & adult & ingest. & $1.9 E-07$ & $2.0 E-08$ & $2.3 E-08$ & - & DOE1988 \\
\hline & & adult & inhal. & $1.1 E-07$ & $2.6 E-07$ & $1.1 E-06$ & $5.2 E-07$ & DOE 1988 \\
\hline \multirow[t]{2}{*}{$1-135$} & $6.61 \mathrm{~h}$ & adult & ingeat. & $2.0 E-06$ & - & $6.7 E-05$ & - & DOE1988 \\
\hline & & edun & Inhal. & $1.1 E-06$ & - & 3.1E-05 & $1.0 E-00$ & DOE 1988 \\
\hline
\end{tabular}

DOE1988

"Internal Dose Convereion Factors for Calculation of Dose to the

ICRP 1989 Public", DOE/EH-0071, July 1988. (based on ICRP Publication 30) -Age-dependent Doses to Members of the Public from Intake of Radionuclides: Part 1", ICRP Pub!cation 56, 1989. 

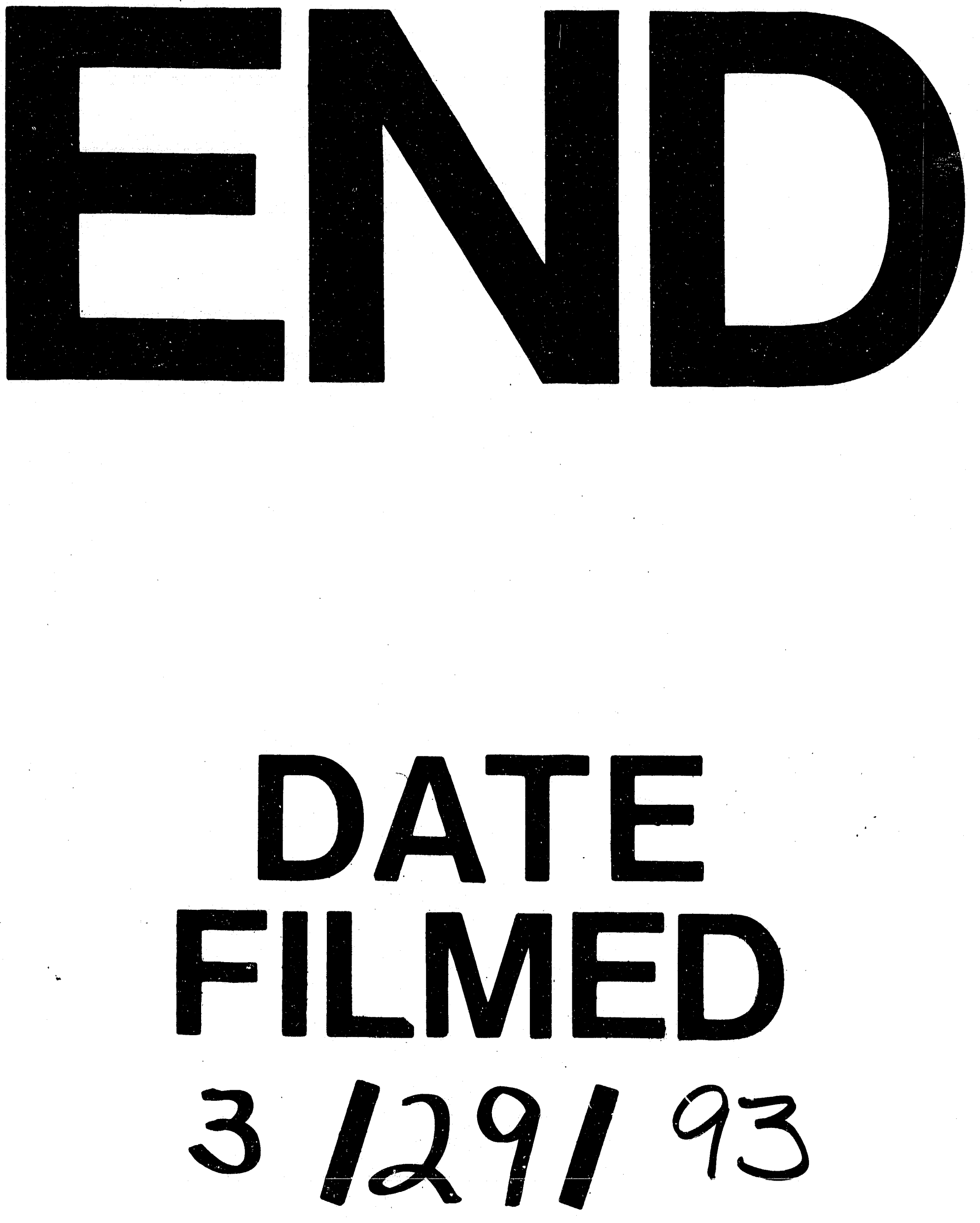
